\title{
Improvement of pea protein isolate powder properties by agglomeration in a fluidized bed: comparison between binder solutions
}

\author{
Nascimento, R. F. ${ }^{\text {a }}$ Andreola, K. ${ }^{\text {a }}$; Rosa, J. G. ${ }^{\text {a,b }}$; Taranto, O. P. ${ }^{\mathbf{a}^{*}}$ \\ a School of Chemical Engineering, University of Campinas, Campinas, São Paulo, Brazil \\ ${ }^{\mathrm{b}}$ Federal Institute of Espírito Santo, Vila Velha, Espírito Santo, Brazil \\ *E-mail of the corresponding author: val@,feq.unicamp.com
}

\begin{abstract}
This study aimed to compare the agglomeration process of pea protein isolate (PPI) using water and aqueous gum Arabic solution as binder liquids. Drying air temperature and binder flow rate were set at $75{ }^{\circ} \mathrm{C}$ and 3.1 $\mathrm{mL} / \mathrm{min}$, respectively. Moisture content, mean particle size, wetting time and flowability were analyzed. Using water as binder liquid, the responses were $(4.0 \pm 0.4) \%, 316.13 \pm 16.73 \mu \mathrm{m}, 10 \mathrm{~s}$ and free flow, respectively. Aqueous gum Arabic solution provided (2.9 \pm 0.5$) \%, 462.67 \pm 51.23 \mu \mathrm{m}, 3 \mathrm{~s}$ and free flow as responses. Gum Arabic solution showed to be a more promising binder.
\end{abstract}

Keywords: Agglomeration; Pulsed fluidized bed; Pea protein isolate; Wetting time; Flowability. 


\section{Introduction}

The food and pharmaceutical industries use fluid bed agglomeration to improve the physicochemical properties of powders, such as wettability, density, flowability and moisture content. ${ }^{[1,2]}$ The improvement of these properties depends on the operating conditions, the properties of the raw material and the binder solution. ${ }^{[2]}$

Fluid bed agglomeration consists of atomizing a binder liquid in a fluidized bed of particles and is considered as successive humidification and drying operations. ${ }^{[3]}$ First, the liquid is atomized into the particles generating liquid bridges; then hot air removes water by transforming the liquid bridges into solid bridges to form agglomerates. ${ }^{[4]}$ This is a complex process because it depends not only on the characteristics of the particulate solid, but also on the operational parameters and properties of the binder solution. ${ }^{[5]}$

The pea exhibits high protein content, ranging from 23 to $33 \%$ depending on the species. In addition, it has a good nutritional value, being rich in essential amino acids, vitamins and minerals. ${ }^{[6,7]}$ Pea protein isolate (PPI) has great potential as a substitute for soy protein in industrial processes. However, the powder produced by spray drying is cohesive rather than instantaneous, consisting of fine particles, limiting its use in the industrial process. ${ }^{[8]}$

The main factors to be considered in the fluidized bed agglomeration process are flow and concentration of the binder solution, atomization pressure, temperature and velocity of fluidization air and bed relative humidity. ${ }^{[5]}$

Thus, the objective of this work was to analyze the influence of binder solutions on the characteristics of agglomerated PPI in pulsed fluidized bed. At the end of the process, the improvement in the wetting time, flowability and particle size distribution of the agglomerated PPI were analyzed.

\section{Materials and Methods}

\subsection{Materials}

Samples containing $0.20 \mathrm{~kg}$ of a commercial PPI (CA Gramkow ${ }^{\circledR}$, Brazil) were used as raw material for all the agglomeration experiments. The PPI contains $6.4 \%$ of moisture, above $80.0 \%$ of protein, $1.12 \%$ of fibers, $7.88 \%$ of lipids, $0.28 \%$ of carbohydrates and about $4.3 \%$ of others constituents. The particle size of raw PPI, measured by laser diffraction and represented by percentiles D10, D50 and D90, were 33.30, 81.0 and 181.92 $\mu \mathrm{m}$, respectively.

The binder solutions were water and aqueous gum Arabic solution, both at room temperature $\left( \pm 27^{\circ} \mathrm{C}\right)$. The concentration of aqueous gum Arabic solution was $15 \% \mathrm{w} / \mathrm{w}$; it was prepared by submitting gum Arabic (Nexira Brasil Comercial, Brazil) and distilled 
water to magnetic stirring until complete dissolution of the binder, which was verified visually.

\subsection{Equipment and process variables}

Experiments were performed in a rotating pulsed fluidized bed (RPFB). Details of this equipment are described by Andreola et al. ${ }^{[9]}$

The following operational conditions were kept fixed: sample mass at $0.2 \mathrm{~kg}$, nozzle height at $300 \mathrm{~mm}$, pulsation frequency at $4 \mathrm{~Hz}$, atomizing air pressure at 7.0 Psi and binder amount at $76 \mathrm{~mL}$. The fluidizing air velocity, fluidizing air temperature and binder flow rate were set at $0,39 \mathrm{~m} / \mathrm{s}, 75^{\circ} \mathrm{C}$ and $3.1 \mathrm{~mL} / \mathrm{min}$, respectively. The operating conditions were selected based on preliminary experiments (data not shown) that were performed to obtain an agglomerated product in stable fluidization conditions. Experimental responses express the average of three replicates.

\subsection{Moisture content, mean particle size and particle size distribution}

The moisture content in the samples was determined by an infrared moisture analyzer (MB200, Ohaus Corporation, USA), that was previously calibrated according to the AOAC standard methodology. ${ }^{[10]}$

The mean particle diameters and particle size distributions of raw and agglomerated PPI were measured by Mastersize S (Malvern Instruments, Malvern, UK).

\subsection{Wetting time and flowability}

Wetting time was measured as the time required for $3 \mathrm{~g}$ of powder to disappear from the surface of water $\left(80 \mathrm{~mL}\right.$ at $\left.27{ }^{\circ} \mathrm{C}\right)$ when the slider that separates the powder and liquid sections were removed. ${ }^{[11]}$ The Hausner index $(H R)$ was calculated from the bulk $\left(\rho_{b}\right)$ and tapped $\left(\rho_{t}\right)$ densities of the raw and agglomerated powder, as shown in Eq. (1).

$$
H R=\frac{\rho_{t}}{\rho_{b}}
$$

Classification of powder flowability based on the $H R$ value is given in Table 1. ${ }^{[12]}$

Table 1. Classification of powder flowability based on the Hausner index (HR)

\begin{tabular}{ll}
\hline \multicolumn{1}{c}{ HR } & \multicolumn{1}{c}{ Flowability } \\
\hline$<1.2$ & Free \\
$1.2-1.4$ & Intermediate \\
$>1.4$ & Non-free \\
\hline
\end{tabular}




\section{Results and discussion}

\subsection{Raw material and binders properties}

Commercial PPI shows density and mean diameter of $1.2659 \pm 0.0035 \mathrm{~g} / \mathrm{cm}^{3}$ and $81.00 \pm$ $0.61 \mu \mathrm{m}$, respectively, and its fluidization behavior could be classified as pertaining to Geldart group A. Wetting time was over $300 \mathrm{~s}$ and $H R$ was 1.3 , classifying the flowability as intermediate. The large particle distribution is the main factor responsible for high wetting time and low flowability, because it provides more compacted bed, decreasing the porosity. ${ }^{[2,9,12]}$

Density, superficial tension and rheology of both liquid binders must be considered. Water presents density of $1.00 \mathrm{~g} / \mathrm{cm}^{3}$, superficial tension of $7.2 \times 10^{6} \mathrm{mN} / \mathrm{m}$ and Newtonian behavior; while gum Arabic solution presents $1.0522 \pm 0.0002 ; 47.35 \pm 0.69$ and pseudoplastic behavior, respectively.

\subsection{Process responses}

\subsubsection{Moisture content}

In agglomeration using water as liquid binder, moisture content reaches $(4.0 \pm 0.4) \%$, while with the use of gum Arabic solution, moisture content was $(2.9 \pm 0.5) \%$, after $24.5 \mathrm{~min}$ of atomization and $10 \mathrm{~min}$ of drying. For both cases, this parameter was at least $2 \%$ lower, getting at $3.5 \%$, compared to the raw material.

Low moisture contents are important mainly for material storage. Temperature at $75{ }^{\circ} \mathrm{C}$ is enough to promote water evaporation of the system, making the product drier. Binder flow rate at $3.1 \mathrm{~mL} / \mathrm{min}$ also provide this type of product, whereas the binder wets the particles less and, when associated with temperature, its evaporation is more effective. ${ }^{[2,9]}$

Fig. 1. shows the relative humidity at bed exit. Although the same temperatures and flow rates were used for both conditions presented, the environment inside the bed remained moister, at least $20 \%$ higher, when the water was used as a binder. The fact that the gum Arabic solution has $15 \%$ solids, can produce this effect, since there is less water available. 


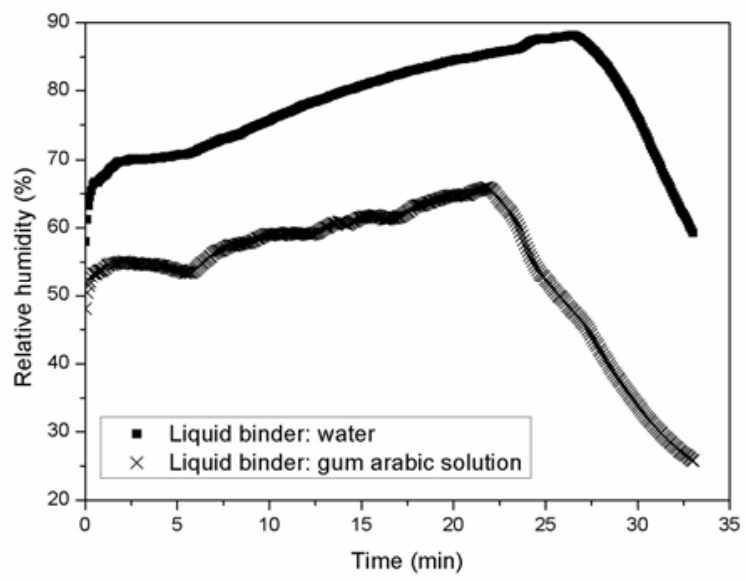

Fig. 1. Relative humidity at bed exit in relation to time.

\subsubsection{Mean particle size and particle size distribution}

Both liquid binders afforded agglomerated PPI with diameter larger than the initial size of raw PPI. To water as binder, particles increased 3.8 times, reaching $316.1 \pm 16.7 \mu \mathrm{m}$, and when gum Arabic solution was used, the particle size reached $462.7 \pm 51.3 \mu \mathrm{m}$, corresponding to a growth of 5.7 times. We also detected several particles with diameter higher than $600 \mu \mathrm{m}$. The particle size distribution to raw and agglomerated PPI is presented in Fig. 2.

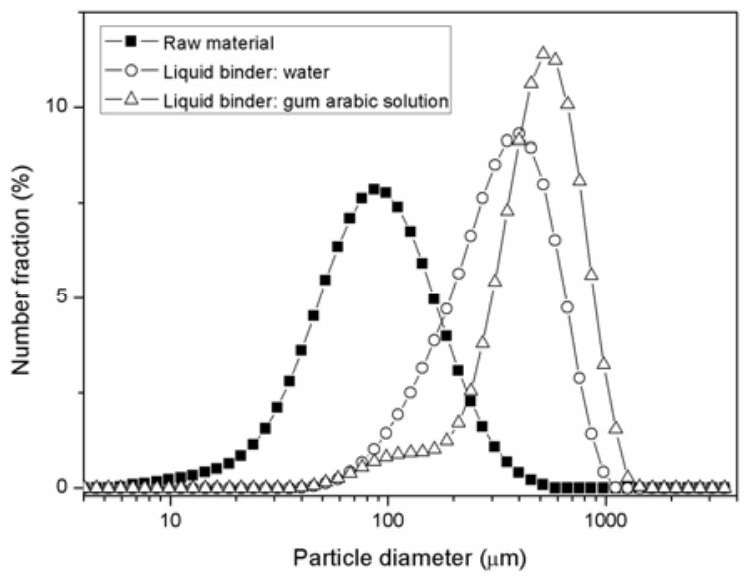

Fig. 2. Particle size distribution of raw and agglomerated PPI.

Agglomerated product also presented fines with diameter of less than $50 \mu \mathrm{m}$, which represented approximately $19 \%$ and $24 \%$ to agglomeration process with water and gum 
Arabic solution, respectively. These fines correspond to non-agglomerated particles and may originate from breaking of the agglomerates by friction within the moving bed.

\subsection{Wetting time}

Compared with raw PPI, agglomerated PPI underwent faster wetting, even though the powders were not completely immersed into water. Agglomerated PPI achieved complete wetting in less than $10 \mathrm{~s}$, to agglomeration with water, and $3 \mathrm{~s}$, to gum Arabic solution which attests to its greater capacity to absorb moisture. It represents a decrease of $97 \%$ and $99 \%$ in wetting time, respectively.

The presence of fine particles allows for a more compact powder during storage, i. e., the smaller particles can penetrate into the spaces between the larger particles, so the product occupies less space. ${ }^{[11,13]}$

\subsection{Flowability}

Agglomeration process with water furnished bed density $\left(\rho_{b}\right)$ of $0.2579 \pm 0.0058 \mathrm{~g} / \mathrm{cm}^{3}$, and compact bed density $\left(\rho_{t}\right)$ of $0.2970 \pm 0.0070 \mathrm{~g} / \mathrm{cm}^{3}$. Already for agglomeration for gum Arabic solution, $\rho_{b}=0.1640 \pm 0.0284 \mathrm{~g} / \mathrm{cm}^{3}$ and $\rho_{t}=0.1939 \pm 0.0284 \mathrm{~g} / \mathrm{cm}^{3}$. The $H R$ values obtained for agglomerated PPI were 1.15 and 1.18 , classifying the product as free. Raw PPI consists of fine particles, which may confer the material a strong cohesive behavior, whereas agglomeration improves PPI flowability. Although the flowability of agglomerated PPI is not yet ideal, this product exhibited significantly better handling properties than raw PPI.

\section{Conclusions}

The particle agglomeration of PPI occurs due to the pulverization of liquid binder on the surfaces of the particles, resulting in a wetted sticky surface and subsequent particle coalescence. On particle drying, the agglomerated structure consolidates, leading to particle enlargement.

Agglomeration of PPI using gum Arabic solution produced larger granules with high flowability and lower cohesiveness when compared to agglomeration with water and spray dried raw material. Additionally, size enlargement also resulted in an improvement of instant properties that was characterized by the higher wettability of the granules. 


\section{Nomenclature}

Greek letters

$$
\rho \quad \text { density } \mathrm{gcm}^{-3}
$$

Subscripts

$\begin{array}{ll}\mathrm{b} & \text { bulk } \\ \mathrm{t} & \text { tapped }\end{array}$

\section{References}

[1] Avilés-Avilés, C., Dumoulin, E., Turchiuli C. Fluidized bed agglomeration of particles with different glass transition temperatures. Powder Technology 2015, 270, 445-452.

[2] Machado, V.G., Hirata, T.A.M., Menegalli, F.C. Agglomeration of soy protein isolate in a pulsed fluidized bed: experimental study and process optimization. Powder Technology 2014, 254, 248-255.

[3] Pont, V.; Saleh, K.; Steinmetz, D.; Hémati, M. Influence of the physicochemical properties on the growth of solid particles by granulation in fluidized bed. Powder Technology 2001, 120, 97-104.

[4] Iveson, S.M.; Litster, J.D.; Hapgood, K.; Ennis, B.J. Nucleation, growth and breakage phenomena in agitated wet granulation processes: a review. Powder Technology 2001, 117, 3-39.

[5] Dacanal, G.C., Menegalli, F.C. Selection of operational parameters for the production of instant soy protein isolate by pulsed fluid bed agglomeration. Powder Technology 2010, 203, 565-573.

[6] Lam, A.C.Y., Karaca, A.C., Tyler, R.T., Nickerson, M.T. Pea protein isolate: structure, extraction, and functionality. Food Reviews International 2018, 34, 126 147.

[7] Muneer, F.; Johansson, E.; Hedenqvist, M.S.; Plivelic, T.S.; Markedal, K.E.; Petersen, I.L.; Sørensen, J.C.; Kuktaite, R. The impacte of newly produced protein and dietary fiber rich fractions of yellow pea (Pisum sativum L.) on the structure and mechanical properties of pasta-like sheets. Food Research International 2018, 106, 607-618.

[8] Boye, J.I., Aksay, S., Roufik, S., Ribéreau, S., Mondor, M., Farnworth, E., Rajamohamed, S.H. Comparison of the functional properties of pea, chickpea and lentil protein concentrates processed using ultrafiltration and isoelectric precipitation techniques. Food Research International 2010, 43, 537-546.

[9] Andreola, K., Silva, C.A.M., Taranto, O.P. Agglomeration and drying of rice protein concentrate in a rotating pulsed fluidized bed: in-line monitoring of particle size. Paper presented at the International Drying Symposium 2016. 
[10] Official Methods of Analysis of the AOAC. Association of Official Analytical Chemists Inc, 1995.

[11] Hogekamp, S., Schubert, H. Rehydration of food powders. Food Science Technology International 2003, 9, 223-235.

[12] Turchiuli, C., Eloualia, Z., El Mansouri, N., Dumoulin, E. Fluidised bed agglomeration: agglomerates shape and end-use properties. Powder Technology 2005, $157,168-175$.

[13] Tonon, R.V., Brabet, C., Hubinger, M.D. Influence of process conditions on the physicochemical properties of acai (Euterpe oleraceae Mart.) powder produced by spray drying. Journal of Food Engineering 2008, 88, 411-418. 